\title{
Biodistribution and elimination kinetics of systemic Stx2 by the Stx2A and Stx2B subunit-specific human monoclonal antibodies in mice
}

Abhineet Sheoran ${ }^{1 *}$, Kwang-il Jeong $^{1,2}$, Jean Mukherjee ${ }^{1}$, Anthony Wiffin ${ }^{1}$, Pradeep Singh ${ }^{3}$ and Saul Tzipori ${ }^{1}$

\begin{abstract}
Background: Hemolytic uremic syndrome (HUS) leading to acute kidney failure, is a condition linked to the production of primarily Shiga toxin 2 (Stx2) by some E. coli serotypes. We have previously shown that Stx2 A subunit-specific human monoclonal antibody (HuMAb) 5C12, and B subunit-specific HuMAb 5 H8 inhibit cultured cell death, and protect mice and piglets from fatal Stx2-intoxication. We have also shown that $5 \mathrm{H} 8$ blocks binding of Stx2 to its cell-surface receptor globotriaosyl ceramide $\left(\mathrm{Gb}_{3}\right)$, whereas Stx2 when complexed with $5 \mathrm{C} 12$ binds $\mathrm{Gb}_{3}$ with higher affinity than Stx2. The mechanism by which 5C12 neutralizes St×2 in vitro involves trapping of Stx2 in the recycling endosomes and releasing it into the extracellular environment. Because of the clinical implications associated with the formation of Stx2/antibody complexes and the potential for trapping and clearance through a severely damaged kidney associated with HUS, we investigated the likely site(s) of Stx2/antibody localization and clearance in intoxicated mice treated with antibody or placebo.

Results: Mice were injected with radiolabeled Stx2 ( $\left.{ }^{125} \mathrm{I}-\mathrm{St} \times 2\right) 4$ hours after administration of 5C12, 5H8, or phosphate buffered saline (PBS) and the sites of localization of labeled Stx2, were investigated 3, 24 and 48 hours later. The liver recorded statistically much higher concentrations of labeled Stx2 for groups receiving 5C12 and 5H8 antibodies after 3, 24 and 48 hours, as compared with the PBS group. In contrast, highest levels of labeled Stx2 were detected in the kidneys of the PBS group at all 3 sampling times. Mice receiving either of the two HuMAbs were fully protected against the lethal effect of Stx2, as compared with the fatal outcome of the control group.

Conclusions: The results suggest that HuMAbs $5 \mathrm{C} 12$ and $5 \mathrm{H} 8$ promoted hepatic accumulation and presumably clearance of toxin/antibody complexes, significantly diverting Stx2 localization in the kidneys, the target of Stx2 and the cause of HUS. This is in contrast to the fatal outcome of the control group receiving PBS. The results also confirm earlier observations that both HuMAbs are highly and equally protective against Stx2 intoxication in mice.
\end{abstract}

Keywords: Shiga toxin, Radiolabel, Antibody, Toxin elimination, Toxin concentration, Pharmacokinetic, Human monoclonal antibody

\footnotetext{
* Correspondence: Abhineet.sheoran@tufts.edu

'Department of Biomedical Sciences, Cummings School of Veterinary

Medicine, Tufts University, 200 Westboro Road Building 20, North Grafton,

MA, USA

Full list of author information is available at the end of the article
} 


\section{Background}

Infection with Shiga toxin (Stx)-producing Escherichia coli (STEC) is the most significant cause of hemolytic uremic syndrome (HUS), the leading cause of acute renal failure in children [1-4]. Of the two antigenically distinct toxins, Stx1 and Stx2, Stx2 is more firmly linked with the development of HUS. Stx 1 and Stx 2 are similar in basic structure [5], binding specificity [5] and mode of action. Epidemiologic studies show that Stx2-producing strains are more frequently associated with HUS than strains that produce both Stx1 and Stx2; while Stx1 alone has rarely been associated with HUS [6-8].

Stx1 and Stx2 consist of an A-subunit monomer and a B-subunit pentamer $[5,9,10]$. The pentameric B subunit binds to its cell surface receptor globotriaosyl ceramide $\left(\mathrm{Gb}_{3}\right.$; Gal 1 1-4Gal $\beta 1-4$ glucosyl ceramide) [11,12]. Internalized Stx follows retrograde transport to the transGolgi network and subsequently to the endoplasmic reticulum and cytosol $[13,14]$. During this trafficking, the A subunit is nicked by the membrane-bound furin protease, generating a catalytically active $\mathrm{N}$-terminal A1 fragment and a C-terminal A2 fragment; both fragments remain linked by a disulfide bond $[13,15]$. The disulfide bond is subsequently reduced, and the active A1 component is released. The released A1 fragment has $\mathrm{N}$-glycosidase catalytic activity and it removes a specific adenine base from the 28S rRNA of the 60S ribosomal subunit [16,17]. Because this adenine base is on a loop of rRNA that is important for elongation factor binding, Stx is able to shut down the protein synthesis and cause cell death.

We have produced human monoclonal antibodies (HuMAbs) against Stx1 and Stx2, and evaluated them in animal models for their efficacy against systemic challenge with the toxins $[18,19]$. We selected $5 \mathrm{C} 12$, a Stx2 A subunit-specific HuMAb, based on its superior efficacy in protecting mice against lethal challenge with Stx2 and Stx2 variants [20] for preclinical evaluation in the piglet diarrhea model challenged orally with STEC. This antibody protected piglets against Stx2-induced fatal neurological symptoms, even when administered well after the onset of diarrhea following oral STEC challenge (48 hours post-challenge) [21]. In this model, diarrheal symptoms precede systemic complications associated with Stx2 uptake from the gut, as is observed in children. Similarly, Stx2 B subunit-specific HuMAb 5 H8 also protects piglets [18] and mice against Stx2 intoxication $[18,21]$.

While these HuMAbs completely protect healthy piglets and mice from Stx2-mediated death, there remains a concern among nephrologists for the potential formation of immune Stx2/antibody complexes in a severely damaged kidney of patients with HUS. In the mouse model, the kidneys are the major target organ of Stx2-intoxication. In this model, Stx2 causes apoptosis of medullary and cortical tubular cells in the kidneys, and leads to renal failure due to the loss of functioning collecting ducts [22]. In the present experiments we investigated the likely site of Stx2/antibody localization and clearance using the mouse model of systemic intoxication treated with these potentially therapeutic antibodies.

\section{Methods}

\section{Stx2}

Stx2, purified from E. coli $\mathrm{C} 600 \mathrm{~W}$ as described previously [23], was obtained from Phoenix Laboratory (Tufts University-NEMC Microbial Products \& Services Facility). The toxin was dissolved at $500 \mu \mathrm{g} / \mathrm{ml}$ in phosphate buffered saline (PBS), aliquoted and stored at $-20^{\circ} \mathrm{C}$.

\section{Stx2-specific HuMAbs}

Production of Stx2A-specific 5C12 and Stx2B-specific 5H8 HuMAbs have been described elsewhere [18,21]. These antibodies were purified by protein A affinity chromatography, dialyzed against PBS, quantified by UV spectrophotometry (ND-1000 Spectrophotometer, Nanodrop), aliquoted, and stored at $-20^{\circ} \mathrm{C}$.

\section{lodination of Stx2}

Purified Stx2 was iodinated by a modification of the chloramine $\mathrm{T}$ method $[24,25]$. Briefly, one millicurie of carrier-free $\mathrm{Na}^{125} \mathrm{I}$ (PerkinElmer, Billerica, MA) was added to 20 to $30 \mu \mathrm{g}$ of Stx 2 in $100 \mu \mathrm{l}$ of PBS. Then, $20 \mu \mathrm{l}$ of chloramine $\mathrm{T}(2.5 \mathrm{mg} / \mathrm{ml}$ in PBS; GFS Chemicals, Columbus, $\mathrm{OH}$ ) was added, and incubated for 20 seconds. The iodination was terminated by adding $20 \mu \mathrm{l}$ of sodium metabisulfite $(5 \mathrm{mg} / \mathrm{ml}$ in distilled water; Sigma, St. Louis, MO). Ten $\mu \mathrm{l}$ of potassium iodide (20 $\mathrm{mg} / \mathrm{ml}$ in PBS; Sigma) was subsequently added to scavenge the free iodine. The iodinated Stx2 $\left({ }^{125} \mathrm{I}-\mathrm{Stx} 2\right)$ was separated from free ${ }^{125}$ I by filtration through a polyacrylamide column (D-salt ${ }^{\mathrm{TM}}$ columns; Pierce, Rockford, IL).

\section{Biodistribution of ${ }^{125} \mathrm{I}-\mathrm{St} \times 2$, and ${ }^{125} \mathrm{I}-\mathrm{St} \times 2 / \mathrm{HuMAb}$ complexes}

The mouse toxicity model [21] was used to study biodistribution of ${ }^{125} \mathrm{I}-\mathrm{Stx} 2$, and ${ }^{125} \mathrm{I}-\mathrm{Stx} 2 / \mathrm{HuMAb}$ complexes. Four-week-old female C57BL/6 mice weighing 18-22 g (Charles River Laboratories) were injected intraperitoneally (IP) with PBS or $30 \mu \mathrm{g} /$ mouse of a Stx2-specific HuMAb (5C12 or $5 \mathrm{H} 8)$. After $4 \mathrm{hr}$, mice were administered intravenously (IV) with $100 \mathrm{ng} /$ mouse (in $100 \mu \mathrm{l}$ of PBS) of ${ }^{125} \mathrm{I}-\mathrm{Stx} 2$ as a single bolus dose. The ${ }^{125} \mathrm{I}-\mathrm{Stx} 2$ dose of $100 \mathrm{ng} /$ mouse is 4 times the LD100 dose [21]. An isotype control was not included in the current experiments as we have consistently found no difference between 
isotype control and PBS groups [21]. The isotype control antibody does not interact with the toxin and mice die within 3 days of either PBS or isotype control antibody administration [21]. Similarly, piglets also succumb to Stx2-mediated systemic complication following either PBS or isotype control antibody administration [21]. A group of 3 mice from each treatment group (5C12 or $5 \mathrm{H} 8$ or $\mathrm{PBS}$ ) was euthanized at $3 \mathrm{~h}, 1$ and 2 days post- ${ }^{125} \mathrm{I}-\mathrm{Stx} 2$ injection. Blood was collected from these mice before euthanasia, and tissues and urine were collected after euthanasia. The fluids and tissues were analyzed for radioactivity by a gamma counter (1470 Wallac wizard, Global Medical Instrumentation, Inc., Ramsey, $\mathrm{MN})$. A group of 5 mice injected IV with $100 \mathrm{ng}$ of ${ }^{125}$ I-BSA was used as a control to the radiolabeled toxin injected group.

Stx2 was labeled again with ${ }^{125} \mathrm{I}$ and the experiment repeated once to obtain 6 mice per treatment group. The data were presented as a percentage of injected dose of radioactive toxin $\left({ }^{125} \mathrm{I}-\mathrm{Stx} 2\right)$ per gram (\% ID/g) of an organ tissue, or per $\mathrm{ml}(\% \mathrm{ID} / \mathrm{ml})$ of a fluid. The $\% \mathrm{ID} / \mathrm{g}$ or\% ID $/ \mathrm{ml}$ was calculated by the formula: (counts per minute or CPM per $\mathrm{ml}$ or per gram / injected CPM) $\mathrm{x}$ 100.

\section{Biological activity of the radiolabeled Stx 2}

The mouse toxicity model was also used to ensure that radiolabeled Stx2 was biologically active and that Stx2specific HuMAbs neutralized the toxin activity. Briefly, $30 \mu \mathrm{g} /$ mouse of a Stx2-specific HuMAb, or PBS, was injected IP $4 \mathrm{hr}$ prior to IV administration of $100 \mathrm{ng}$ ${ }^{125} \mathrm{I}-\mathrm{Stx} 2 /$ mouse. Mice were observed 3 or more times daily for clinical signs and survival until 11 day posttoxin administration.

All animal studies described in the above 2 sections were performed in accordance with the guidelines of the Institutional Animal Care and Use Committee, Tufts University.

\section{Statistical analysis}

For statistical analysis of total radioactivity remaining in the body following $3 \mathrm{~h}, 1$ and 2 days of ${ }^{125} \mathrm{I}-\mathrm{Stx} 2$ injection in different treatment groups, the pair wise comparison was done using Student t-test and Wilcoxon rank test. For statistical analysis of radioactivity in each organ at a particular time point $(3 \mathrm{~h}, 1$ day or 2 days post- ${ }^{125}$ I-Stx2 injection), nonparametric Kruskal-Wallis and Wilcoxon rank tests were performed to evaluate significant differences among the four treatment groups. The analyses were performed using statistical software (SAS 9.2). Resulting p-values of less than 0.05 were considered significant.

\section{Results}

Biological activity of radiolabeled $\left({ }^{125} \mathrm{I}-\mathrm{Stx} 2\right)$ and neutralization of ${ }^{125}$ I-Stx2 by Stx2-specific HuMAbs

Purified Stx2 consisted of only A and B subunits (Figure 1A). ${ }^{125} \mathrm{I}-\mathrm{Stx} 2$ was biologically active as none of the mice survived ${ }^{125} \mathrm{I}-\mathrm{Stx} 2$ challenge in the PBS group (Figure 1B). They either died or became severely ill and were euthanized 57-64 h or 2.3-2.6 days following toxin administration (Figure 1B). All Stx2specific HuMAbs neutralized the lethal biological activity of ${ }^{125}$ I-Stx2 as all mice in HuMAb groups survived the ${ }^{125} \mathrm{I}-\mathrm{Stx} 2$ challenge until the end of the experiment (264 h or 11 day post-toxin challenge) (Figure 1B).

\section{Distribution of ${ }^{125} \mathrm{I}-\mathrm{Stx} 2$, and ${ }^{125} \mathrm{I}-\mathrm{Stx} 2 / \mathrm{HuMAb}$ complexes in blood}

In the control ${ }^{125}$ I-BSA group, $98 \%$ of ${ }^{125}$ I-BSA was eliminated from the body, and most of the remaining $2 \%$ ${ }^{125}$ I-BSA was localized in urine and blood 1 day post${ }^{125}$ I-BSA administration (results not shown).

At $3 \mathrm{~h}$ post- ${ }^{125} \mathrm{I}-\mathrm{Stx} 2$ administration, the toxin localized significantly more in blood of groups receiving HuMAbs $5 \mathrm{C} 12$ or $5 \mathrm{H} 8$ than the PBS group (Figure 2). However, the concentration of the toxin between the HuMAb groups did not differ significantly at this time point.

On days 1 and 2, the toxin localized significantly more in blood of groups receiving HuMAbs $5 \mathrm{C} 12$ than the $\mathrm{PBS}$ and $5 \mathrm{H} 8$ groups (Figure 2). The toxin concentration did not differ significantly between $5 \mathrm{H} 8$ and PBS. On

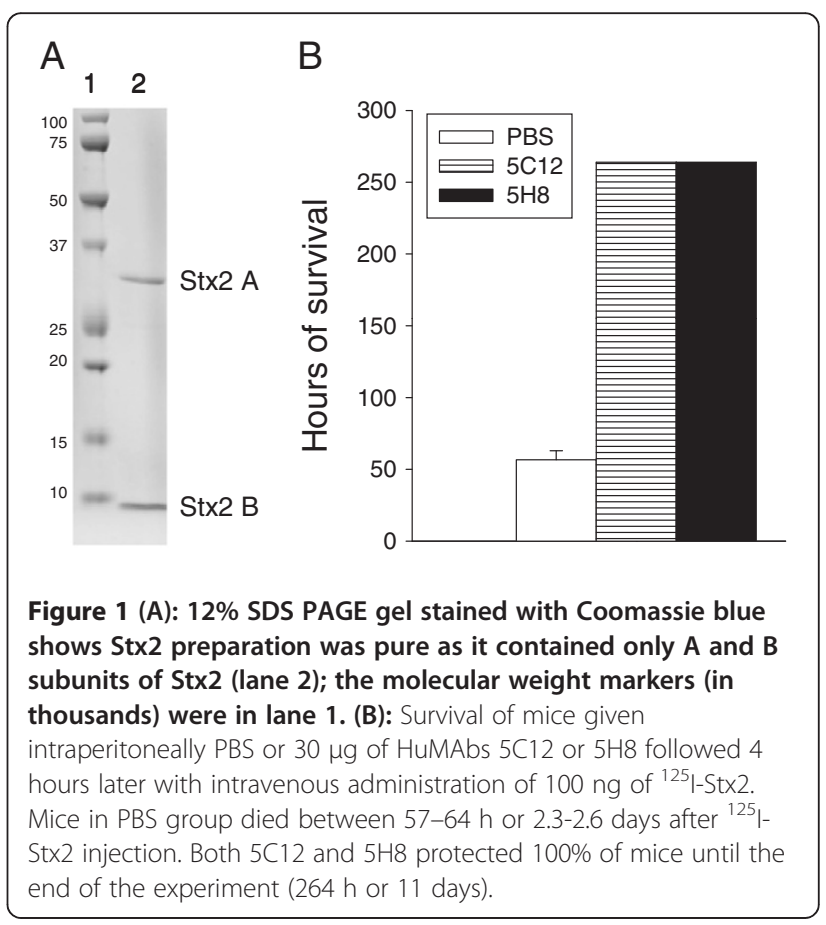




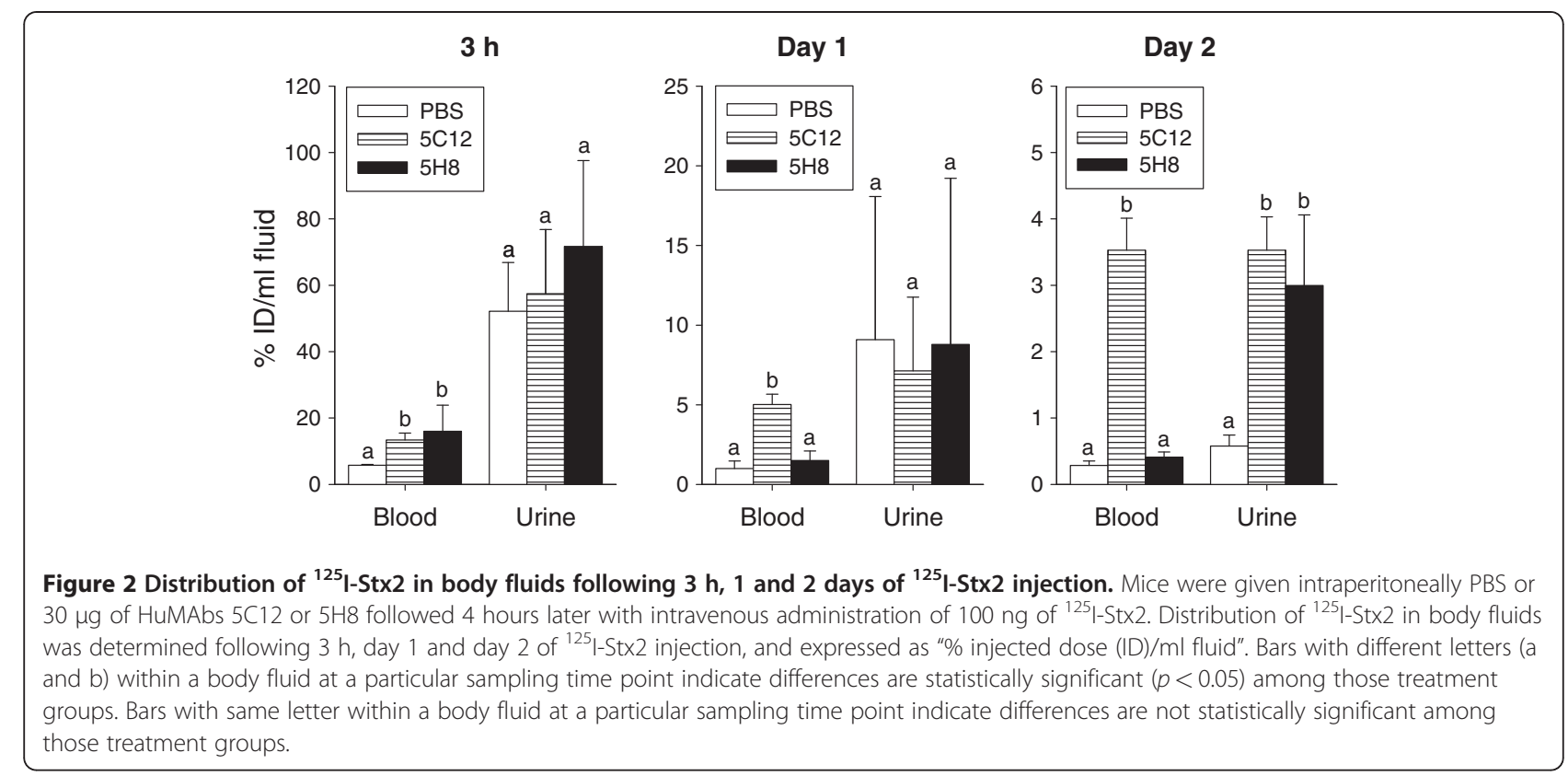

these days, the relative mean toxin concentration in blood in each group was: $5 \mathrm{C} 12>5 \mathrm{H} 8>\mathrm{PBS}$ (Figure 2).

\section{Distribution of ${ }^{125} \mathrm{I}-\mathrm{St} \times 2$, and ${ }^{125} \mathrm{I}-\mathrm{St} \times 2 /$ HuMAb complexes in urine}

Excretion of radioactivity in urine did not differ significantly between treatment groups at $3 \mathrm{~h}$ and 1 day after ${ }^{125}$ I-Stx2 administration (Figure 2). On day 2, the radioactivity localized significantly more in the urine of HuMAb groups than the PBS group (Figure 2).

\section{Distribution of ${ }^{125} \mathrm{I}-\mathrm{St} \times 2$, and ${ }^{125} \mathrm{I}-\mathrm{St} \times 2 /$ HuMAb complexes in tissues}

At $3 \mathrm{~h}$, the toxin concentration in the PBS group was significantly different from both $5 \mathrm{C} 12$ and $5 \mathrm{H} 8$ antibody treatment groups in only two organs, the kidneys and the liver (Figure 3 and Table 1). In the cerebrum, the toxin concentration in the $5 \mathrm{H} 8$ group was significantly different from the $\mathrm{PBS}$ and $5 \mathrm{C} 12$ groups, and in the stomach, the toxin concentration in the $5 \mathrm{H} 8$ group was significantly different from the $5 \mathrm{C} 12$ group but not from the PBS group (Figure 3). In the mesenteric lymph nodes $(\mathrm{MLN})$, the toxin concentration in the $5 \mathrm{H} 8$ group differed significantly from the PBS group but not from the $5 \mathrm{C} 12$ group (Figure 3). The toxin concentration in any of the remaining organs did not differ significantly between any treatment groups (Figure 3, Additional file 1: Table $\mathrm{S} 1)$. Based on the numerical mean radioactivity concentration, highest concentrations were found in the kidneys (41\%), liver (23\%) and liver (25\%) of PBS, 5C12 and 5H8 groups, respectively (Figure 3 and Table 1 ). While the toxin concentration in the kidneys was significantly greater in the PBS group than the HuMAb groups, it did not differ significantly among kidneys of the 5C12 and $5 \mathrm{H} 8$ groups. The toxin concentration in the liver was significantly higher in the $5 \mathrm{C} 12$ and $5 \mathrm{H} 8$ groups than in the PBS group but did not differ significantly between the $5 \mathrm{C} 12$ and $5 \mathrm{H} 8$ groups.

On day 1 , the toxin concentration in the PBS group again differed significantly from both $5 \mathrm{C} 12$ and $5 \mathrm{H} 8$ antibody treatment groups in only two organs, the kidneys and the liver (Figure 3 and Table 1). In the MLN, the toxin concentration in the $5 \mathrm{H} 8$ group differed significantly from the PBS and $5 \mathrm{C} 12$ groups (Figure 3 ), and in the heart, the toxin concentration in the PBS group differed significantly from the $5 \mathrm{C} 12$ group but not from the $5 \mathrm{H} 8$ group (Additional file 1: Table S1). The toxin concentration in any of the remaining organs did not differ significantly between any treatment groups (Figure 3, Additional file 1: Table S1). Maximal levels of Stx2 localized in the kidneys of PBS (43\%) group, in the kidneys (11\%) and liver (8\%) of 5H8 group, and in the liver, spleen and kidneys ( 10\%) of 5C12 group (Figure 3 and Table 1). Liver was a major organ of toxin accumulation in $5 \mathrm{H} 8$ and $5 \mathrm{C} 12$ groups but not in PBS (4\%) group. The toxin concentration in the kidneys of the PBS group was significantly greater than in the kidneys of the $5 \mathrm{C} 12$ and $5 \mathrm{H} 8$ groups. The toxin concentration in the liver of the PBS was significantly lower than that of the $5 \mathrm{C} 12$ and $5 \mathrm{H} 8$ groups. The toxin concentration in the liver and kidneys did not differ significantly between the $5 \mathrm{C} 12$ and $5 \mathrm{H} 8$ groups.

On day 2, based on the numerical means, the kidneys were the organ where maximum toxin accumulated in the PBS (13\%) group, whereas maximal levels of the toxin in the $5 \mathrm{H} 8$ group localized in the liver and spleen 

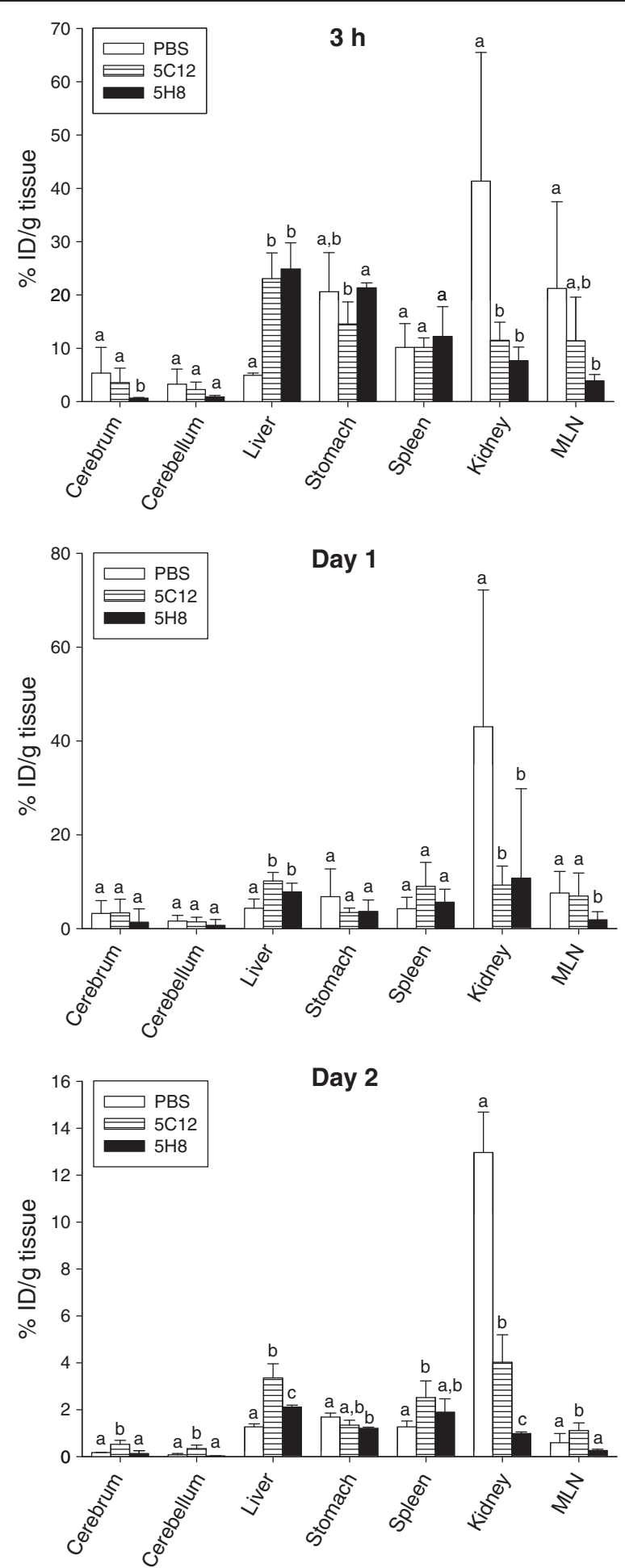

Figure 3 Distribution of ${ }^{125} \mathrm{I}$-Stx 2 in tissues following $3 \mathrm{~h}, 1$ and 2 days of ${ }^{125} \mathrm{I}$-Stx 2 injection. Mice were given intraperitoneally PBS or 30 $\mu \mathrm{g}$ of HuMAbs $5 \mathrm{C} 12$ or $5 \mathrm{H} 8$ followed 4 hours later with intravenous administration of $100 \mathrm{ng}$ of ${ }^{125}$ I-Stx2. Distribution of ${ }^{125}$ I-Stx 2 in body tissues was determined following $3 \mathrm{~h}$, day 1 and day 2 of ${ }^{125}$ I-Stx2 injection, and expressed as "\% injected dose (ID)/g tissue". Bars with different letters $(a-c)$ within a tissue indicate differences are statistically significant $(p<0.05)$ among those treatment groups. Bars with same letter within a tissue indicate differences are not statistically significant among those treatment groups. 
Table 1 Distribution of ${ }^{125}$ I-Stx 2 in the kidney and liver following $3 \mathrm{~h}, 1$ day and 2 days of ${ }^{125}$ I-Stx 2 injection ${ }^{1}$

\begin{tabular}{|c|c|c|c|c|}
\hline Sampling time & Tissue & PBS & $5 C 12$ & $5 \mathrm{H} 8$ \\
\hline \multirow[t]{2}{*}{$3 \mathrm{~h}$} & Kidney & $41 \pm 24.1^{a}$ & $11 \pm 3.4^{b}$ & $8 \pm 2.6^{b}$ \\
\hline & Liver & $5 \pm 0.4^{a}$ & $23 \pm 4.8^{b}$ & $25 \pm 4.9^{b}$ \\
\hline \multirow[t]{2}{*}{ Day 1} & Kidney & $43 \pm 29.1^{a}$ & $9 \pm 4.0^{b}$ & $11 \pm 19.1^{b}$ \\
\hline & Liver & $4 \pm 1.9^{a}$ & $10 \pm 1.8^{b}$ & $8 \pm 1.9^{b}$ \\
\hline \multirow[t]{2}{*}{ Day 2} & Kidney & $13 \pm 1.7^{a}$ & $4 \pm 1.2^{b}$ & $1 \pm 0 . c^{c}$ \\
\hline & Liver & $1 \pm 0.1^{a}$ & $3 \pm 0.6^{b}$ & $2 \pm 0.1^{c}$ \\
\hline
\end{tabular}

${ }^{1}$ Distribution of ${ }^{125} \mathrm{I}$-Stx2 in the kidney and the liver following $3 \mathrm{~h}, 1$ day and 2 days of ${ }^{125} \mathrm{I}$-Stx2 injection. Mice were given intraperitoneally PBS or $30 \mu \mathrm{g}$ of HuMAbs $5 \mathrm{C} 12$ or $5 \mathrm{H} 8$ followed 4 hours later with intravenous administration of $100 \mathrm{ng}$ of ${ }^{125} \mathrm{I}$-Stx2. Distribution of ${ }^{125} \mathrm{I}$-Stx2 in the kidney and the liver was determined following $3 \mathrm{~h}, 1$ day and 2 days of ${ }^{125} \mathrm{I}$-Stx2 injection, and expressed as "\% injected dose (ID)/g tissue".

$a-c$ Values with different letters (superscripts ' $a$ ', ' $b$ ' and ' $c$ ') within a tissue indicate differences are statistically significant $(p<0.05)$ among those treatment groups. Values with same letter superscript within a tissue indicate differences are not statistically significant among those treatment groups.

(2\%), and in the 5 C12 group in the liver, kidneys and spleen (3-4\%) (Figure 3 and Table 1). Significantly more toxin localized in the livers of the $5 \mathrm{C} 12$ and $5 \mathrm{H} 8$ groups than the liver of PBS group. The toxin was barely detectable in cerebrum and cerebellum (Figure 3), and other organs (Additional file 1: Table S1).

\section{Discussion}

The purpose of this investigation was to establish the site (s) of Stx2 accumulation in the intoxicated host, and whether administration of highly protective antibodies impacts this outcome. In addition, the site of accumulation of Stx2/antibody complexes in patients with HUS is of particular concern to nephrologists, should the site be the kidneys leading to further renal dysfunction. The results of the present study suggest that HuMAbs $5 \mathrm{C} 12$ and $5 \mathrm{H} 8$ facilitated hepatic clearance of Stx2 as maximal levels of radioactivity in these groups were present in the liver at $3 \mathrm{~h}$ after ${ }^{125} \mathrm{I}-\mathrm{Stx} 2$ administration. The liver was also a major organ of radioactivity accumulation in these 2 groups at day 1 and day 2 sampling times, largely sparing the kidney. In contrast, kidneys were the major target organ of ${ }^{125}$ I-Stx2 accumulation in the PBS group at all 3 sampling times, indicating that rapid hepatic elimination of Stx2 did not occur in this group. Other studies have previously shown that soluble immune complexes are cleared primarily by the liver through uptake into Kupffer cells [26-28].

The results of the present study show that accumulation of Stx2 in the kidneys is significantly blocked by the HuMAbs $5 \mathrm{C} 12$ and $5 \mathrm{H} 8$ as radioactivity accumulated in the kidneys of these two groups at much lower levels than the kidneys of the PBS group. As all mice in the 5C12 and $5 \mathrm{H} 8$ groups did not show any clinical signs of Stx2-intoxication and survived, the renal presence of Stx2 in these mice appear to have had minimal clinical impact. In contrast, all mice in the PBS group succumbed to Stx2intoxication, and toxin presence in the kidneys of this group may have contributed to their deaths. Stx2 in the kidneys of mice is toxic and causes apoptosis of medullary and cortical tubular cells, and renal failure due to the loss of functioning collecting ducts [22]. These results suggest that $\mathrm{Stx} 2 / 5 \mathrm{C} 12$ or Stx $2 / 5 \mathrm{H} 8$ complexes are less likely to accumulate in the kidneys in patients with HUS, and less likely to exacerbate the condition further.

Gb3 expression on neuronal cells in mouse central nervous system and its binding with Stx2 has recently been shown [29], which also explains earlier observations of Stx2 localization in the spinal cord [30]. In the present study, significantly more toxin was measured in the cerebrum but not cerebellum of the PBS and 5C12 groups than in the $5 \mathrm{H} 8$ group at the $3 \mathrm{~h}$ sampling time. This suggests that toxin can bind to the cerebrum but not the cerebellum, and that $5 \mathrm{H} 8$ but not $5 \mathrm{C} 12$ can block this binding. Significant differences in toxin accumulation in cerebrum or cerebellum did not occur on day 1 or day 2 in any of the groups. Note however, that in the present study, cerebral toxin accumulation in PBS and $5 \mathrm{C} 12$ groups was much less than the accumulation of toxin in the kidney, a well known target of Stx2. The spinal cord was not included in the present study.

The stomach was one of the major organs of radioactivity accumulation (especially at $3 \mathrm{~h}$ sampling time) in all treatment groups. The stomach has previously been shown to accumulate radioactivity in mice injected with radiolabeled Stx2 [30]. Presumably, sequestration of the released radioiodide in the stomach may have occurred due to the dehalogenation effect [31].

Rutjes et al. [30] reported that the highest concentrations of Stx2 localized in the nasal turbinates followed by the lungs and kidneys. Stx2-specific antibodies were not used in that study [30]. The lungs, but not the nasal turbinates were included in the present study, and with regards to toxin concentration, they were the fourth highest in the PBS and 5H8 groups, and the sixth highest in $5 \mathrm{C} 12$ group at $3 \mathrm{~h}$ sampling time (Figure 3, Additional file 1: Table S1). As the previous [30] and the present studies used radioiodinated Stx 2 and the IV route of toxin administration, the discrepancy between the two investigations may be related to sampling time after 
toxin administration ( $1 \mathrm{~h}$ vs. $3 \mathrm{~h}$ in our study), and/or the strain of mouse used (Balb/c vs. C57BL/6 in our study). Nevertheless, the kidney was a major target organ for Stx 2 in both studies [30]. Stx2 is known to have a propensity for lymphoid cells [32-34] as is shown by binding of the toxin within MLN in the present study.

\section{Conclusions}

The results of the present study suggest that the interaction of Stx 2 with HuMAbs 5C12 and 5H8 inhibited accumulation of the toxin in the kidney, the major target organ of Stx2-intoxication, and lead instead to rapid accumulation of Stx2 in the liver, an organ known to clear soluble immune complexes in vivo [26-28].

\section{Additional file}

Additional file 1: Table S1. Distribution of ${ }^{125} 1-S t \times 2$ in body fluids and tissues following 3 h, 1 day and 2 days of ${ }^{125}$ I-Stx2 injection. ${ }^{1}$

\begin{abstract}
Abbreviations

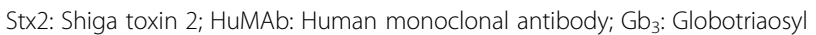
ceramide; I-Stx2: Radiolabeled Stx2; PBS: Phosphate buffered saline; STEC: Shiga toxin-producing Escherichia coli; HUS: Hemolytic uremic syndrome; \% ID/g: Percentage of injected dose of radioactive toxin per gram of an organ tissue; \% ID/ml: Percentage of injected dose of radioactive toxin per $\mathrm{ml}$ of a fluid; CPM: Counts per minute; MLN: Mesenteric lymph nodes.
\end{abstract}

\section{Competing interests}

The authors have declared that no competing interests of any kind exist.

\section{Acknowledgements}

We thank Dr. Anne Kane, Phoenix Laboratory, Tufts-NEMC Microbial Products \& Services Facility, for providing the purified Stx2. We also thank Dr. Giovanni Widmer for review of the manuscript. This study was funded with Federal funds from the NIAID, NIH, DHHS, under contract number N01-Al-30050.

\section{Author details}

'Department of Biomedical Sciences, Cummings School of Veterinary Medicine, Tufts University, 200 Westboro Road Building 20, North Grafton, MA, USA. ${ }^{2}$ Vaccine Research Center, 401 North Middletown Road Pfizer, Pearl River, NY 10965, USA. ${ }^{3}$ Department of Mathematics, Southeast Missouri State University, 401 North Middletown Road Pfizer, Cape Girardeau, MO 63701, USA.

\section{Authors' contributions}

AS conceived and designed the experiments, and contributed to all aspects of this research; KJ, JM and AW performed the experiments; AS and PS analyzed the data; AS wrote the manuscript; ST and JM contributed to writing the manuscript, and KJ helped in addressing the reviewers' comments. All authors read and approve the final manuscript.

Received: 8 March 2012 Accepted: 1 June 2012

Published: 1 June 2012

\section{References}

1. Boerlin P, McEwen SA, Boerlin-Petzold F, Wilson JB, Johnson RP, Gyles $C L$ : Associationbetween virulence factors of Shiga toxin-producing Escherichia coli and disease in humans. J Clin Microbiol 1999, 37:497-503.

2. Griffin PM, Tauxe RV: The epidemiology of infections caused by Escherichia coli 0157:H7, other enterohemorrhagic E. coli, and the associated hemolytic uremic syndrome. Epidemiol Rev 1991, 13:60-98.

3. Milford DV, Taylor CM, Guttridge B, Hall SM, Rowe B, Kleanthous H: Haemolytic uraemic syndromes in the British Isles 1985-8: association with verocytotoxin producing Escherichia coli. Part 1: Clinical and epidemiological aspects. Arch Dis Child 1990, 65:716-721.

4. Ostroff SM, Tarr PI, Neill MA, Lewis JH, Hargrett-Bean N, Kobayashi JM: Toxin genotypes and plasmid profiles as determinants of systemic sequelae in Escherichia coli 0157:H7 infections. J Infect Dis 1989, 160:994-998.

5. Fraser ME, Fujinaga M, Cherney MM, Melton-Celsa AR, Twiddy EM, O'Brien $A D$, James MN: Structure of shiga toxin type 2 (Stx2) from escherichia coli O157:H7. J Biol Chem 2004, 279:27511-27517.

6. Friedrich AW, Bielaszewska M, Zhang WL, Pulz M, Kuczius T, Ammon A, Karch H: Escherichia coli harboring Shiga toxin 2 gene variants: frequency and association with clinical symptoms. J Infect Dis 2002, 185:74-84.

7. Russmann H, Schmidt H, Heesemann J, Caprioli A, Karch H: Variants of Shiga-like toxin II constitute a major toxin component in Escherichia coli 0157 strains from patients with haemolytic uraemic syndrome. J Med Microbiol 1994, 40:338-343.

8. Tzipori S, Sheoran A, Akiyoshi D, Donohue-Rolfe A, Trachtman H: Antibody therapy in the management of shiga toxin-induced hemolytic uremic syndrome. Clin Microbiol Rev 2004, 17:926-941. table of contents.

9. Ling H, Boodhoo A, Hazes B, Cummings MD, Armstrong GD, Brunton JL, Read RJ: Structure of the shiga-like toxin I B-pentamer complexed with an analogue of its receptor Gb3. Biochemistry 1998, 37:1777-1788.

10. Shimizu H, Field RA, Homans SW, Donohue-Rolfe A: Solution structure of the complex between the B-subunit homopentamer of verotoxin VT-1 from Escherichia coli and the trisaccharide moiety of globotriaosylceramide. Biochemistry 1998, 37:11078-11082.

11. Lingwood CA, Law H, Richardson S, Petric M, Brunton JL, De Grandis S, Karmali M: Glycolipid binding of purified and recombinant Escherichia coli produced verotoxin in vitro. J Biol Chem 1987, 262:8834-8839.

12. Waddell T, Head S, Petric M, Cohen A, Lingwood C: Globotriosyl ceramide is specifically recognized by the Escherichia coli verocytotoxin 2. Biochem Biophys Res Commun 1988, 152:674-679.

13. Garred O, Dubinina E, Holm PK, Olsnes S, van Deurs B, Kozlov JV, Sandvig K: Role of processing and intracellular transport for optimal toxicity of Shiga toxin and toxin mutants. Exp Cell Res 1995, 218:39-49.

14. Sandvig K, van Deurs B: Endocytosis, intracellular transport, and cytotoxic action of Shiga toxin and ricin. Physiol Rev 1996, 76:949-966.

15. Garred O, van Deurs B, Sandvig K: Furin-induced cleavage and activation of Shiga toxin. J Biol Chem 1995, 270:10817-10821.

16. Endo Y, Tsurugi K, Yutsudo T, Takeda Y, Ogasawara T, Igarashi K: Site of action of a Vero toxin (VT2) from Escherichia coli O157:H7 and of Shiga toxin on eukaryotic ribosomes. RNA N-glycosidase activity of the toxins. Eur J Biochem 1988, 171:45-50.

17. Saxena SK, O'Brien AD, Ackerman EJ: Shiga toxin, Shiga-like toxin II variant, and ricin are all single-site RNA N-glycosidases of 28S RNA when microinjected into Xenopus oocytes. J Biol Chem 1989, 264:596-601.

18. Mukherjee J, Chios K, Fishwild D, Hudson D, O'Donnell S, Rich SM, Donohue-Rolfe A, Tzipori S: Human Stx2-specific monoclonal antibodies prevent systemic complications of Escherichia coli 0157:H7 infection. Infect Immun 2002, 70:612-619.

19. Mukherjee J, Chios K, Fishwild D, Hudson D, O'Donnell S, Rich SM, Donohue-Rolfe A, Tzipori S: Production and characterization of protective human antibodies against Shiga toxin 1. Infect Immun 2002, 70:5896-5899.

20. Sheoran AS, Chapman S, Singh P, Donohue-Rolfe A, Tzipori S: Stx2-specific human monoclonal antibodies protect mice against lethal infection with Escherichia coli expressing Stx2 variants. Infect Immun 2003, 71:31253130.

21. Sheoran AS, Chapman-Bonofiglio S, Harvey BR, Mukherjee J, Georgiou G, Donohue-Rolfe A, Tzipori S: Human antibody against shiga toxin 2 administered to piglets after the onset of diarrhea due to Escherichia coli 0157:H7 prevents fatal systemic complications. Infect Immun 2005, 73:4607-4613.

22. Psotka MA, Obata F, Kolling GL, Gross LK, Saleem MA, Satchell SC, Mathieson PW, Obrig TG: Shiga toxin 2 targets the murine renal collecting duct epithelium. Infect Immun 2009, 77:959-969.

23. Donohue-Rolfe A, Acheson DW, Kane AV, Keusch GT: Purification of Shiga toxin and Shiga-like toxins I and II by receptor analog affinity chromatography with immobilized P1 glycoprotein and production of cross-reactive monoclonal antibodies. Infect Immun 1989, 57:3888-3893. 
24. Hunter WM, Greenwood FC: Preparation of iodine-131 labelled human growth hormone of high specific activity. Nature 1962, 194:495-496.

25. Fuchs G, Mobassaleh M, Donohue-Rolfe A, Montgomery RK, Grand RJ, Keusch GT: Pathogenesis of Shigella diarrhea: rabbit intestinal cell microvillus membrane binding site for Shigella toxin. Infect Immun 1986, 53:372-377.

26. Davies KA, Robson MG, Peters AM, Norsworthy P, Nash JT, Walport MJ: Defective Fc-dependent processing of immune complexes in patients with systemic lupus erythematosus. Arthritis Rheum 2002, 46:1028-1038.

27. Johansson AG, Lovdal T, Magnusson KE, Berg T, Skogh T: Liver cell uptake and degradation of soluble immunoglobulin $\mathrm{G}$ immune complexes in vivo and in vitro in rats. Hepatology 1996, 24:169-175.

28. Lovdal T, Andersen E, Brech A, Berg T: Fc receptor mediated endocytosis of small soluble immunoglobulin $\mathrm{G}$ immune complexes in Kupffer and endothelial cells from rat liver. J Cell Sci 2000, 113(Pt 18):3255-3266.

29. Obata F, Tohyama K, Bonev AD, Kolling GL, Keepers TR, Gross LK, Nelson MT, Sato S, Obrig TG: Shiga toxin 2 affects the central nervous system through receptor globotriaosylceramide localized to neurons. J Infect Dis 2008, 198:1398-1406.

30. Rutjes NW, Binnington BA, Smith CR, Maloney MD, Lingwood CA: Differential tissue targeting and pathogenesis of verotoxins 1 and 2 in the mouse animal model. Kidney Int 2002, 62:832-845.

31. Shen DH, Kloos RT, Mazzaferri EL, Jhian SM: Sodium iodide symporter in health and disease. Thyroid 2001, 11:415-425.

32. Cohen A, Madrid-Marina V, Estrov Z, Freedman MH, Lingwood CA, Dosch HM: Expression of glycolipid receptors to Shiga-like toxin on human B lymphocytes: a mechanism for the failure of long-lived antibody response to dysenteric disease. Int Immunol 1990, 2:1-8.

33. Menge C, Wieler LH, Schlapp T, Baljer G: Shiga toxin 1 from Escherichia coli blocks activation and proliferation of bovine lymphocyte subpopulations in vitro. Infect Immun 1999, 67:2209-2217.

34. Sugatani J, Igarashi T, Shimura M, Yamanaka T, Takeda T, Miwa M: Disorders in the immune responses of T- and B-cells in mice administered intravenous verotoxin 2. Life Sci 2000, 67:1059-1072.

doi:10.1186/1471-2172-13-27

Cite this article as: Sheoran et al:: Biodistribution and elimination kinetics of systemic Stx2 by the Stx2A and Stx2B subunit-specific human monoclonal antibodies in mice. BMC Immunology 2012 13:27.

\section{Submit your next manuscript to BioMed Central and take full advantage of:}

- Convenient online submission

- Thorough peer review

- No space constraints or color figure charges

- Immediate publication on acceptance

- Inclusion in PubMed, CAS, Scopus and Google Scholar

- Research which is freely available for redistribution 